\title{
ATF3 wt Allele
}

National Cancer Institute

\section{Source}

National Cancer Institute. ATF3 wt Allele. NCI Thesaurus. Code C103960.

Human ATF3 wild-type allele is located in the vicinity of $1 \mathrm{q} 32.3$ and is approximately $55 \mathrm{~kb}$ in length. This allele, which encodes cyclic AMP-dependent transcription factor AT F-3 protein, is involved in both transcriptional repression and DNA binding. 